\title{
Growth and sugarcane cultivars productivity under notillage and reduced tillage system ${ }^{1}$
}

\author{
Sálvio Napoleão Soares Arcoverde ${ }^{*}$ D , Cristiano Márcio Alves de Souza ${ }^{2}$, Hideo de Jesus Nagahama \\ Munir Mauad ${ }^{2}$ Egas Jose Armando², Jorge Wilson Cortez ${ }^{2}$ \\ $10.1590 / 0034-737 X 201966030002$
}

\begin{abstract}
This study aims to evaluate the growth and yield of the sugarcane plant cultivars, and their correlation to soil mechanical penetration resistance in a Dystroferric Red Oxisol submitted to reduced tillage and, no-tillage systems. Eight sugarcane plant cultivars (RB965902, RB985476, RB966928, RB855156, RB975201, RB975242, RB036066 and RB855536) were in each soil preparation system, and the trial was conducted in a completely randomized design and eight treatments and four replications. The trial evaluated: number of tillers per meter, stalks height and diameter, and stalks yield and sugar content. Additionally, were evaluated the soil mechanical penetration resistance (PR) and soil moisture. The highest rates of daily elongation, yield of stalks and sugar content were observed under no - tillage, due to the lower soil mechanical penetration resistance and higher soil moisture. The cultivar RB966928 presented higher values for growth, yield of stalks and sugar content, while RB855536 and the medium to late maturity cultivars RB975201, RB975242, RB036066, which had either a lower stalk growth rate or presented lower number at the end of the cycle in both soil tillage.
\end{abstract}

Keywords: Saccharum spp.; cane-plant; soil management.

\section{INTRODUCTION}

The sugarcane farming system involves several successive mechanized operations, starting from soil preparation, planting to harvest and transportation of the raw material. The initial soil management influences its structure, on regard to the fundamental physical-water properties, such as aeration porosity, crop water availability, soil water retention, nutrient absorption and soil water infiltration (Silva \& Castro, 2015), as well as the factors related to $\mathrm{pH}$ alteration and root system environment (Tavares et al., 2010; Cury et al., 2014). These conditions imposed by the soil management systems, influence directly the performance of sugarcane varieties cultivated in clayey soils (Carvalho et al., 2011; Silva Junior et al., 2013).

Concerning to the sustainability of sugarcane agroecosystems, is doubtful the adoption of the conventional soil preparation system in sugar cane implantation regarding to the impacts of successive operations in areas previously cultivated with grains, which generally do not have restrictions on soil fertility and soil physical impairment (Carvalho et al., 2011).

Soil preparation system involving conservationist methods, such as no-tillage and reduced-tillage systems, to enable soil minimal disturbance, soil surface coverage from previous crop residues, improve its structure, reducing energy expenditure (Arcoverde et al., 2019a). Nevertheless,

\footnotetext{
Submitted on October $30^{\text {th }}, 2018$ and accepet on May 14 th, 2019.

${ }^{1}$ This work is part of the first author's doctoral thesis.

${ }^{2}$ Universidade Federal da Grande Dourados, PNPD/PGEA, Dourados, Mato Grosso do Sul, Brazil. salvionapoleao@gmail.com; csouza@ufgd.edu.br; MunirMauad@ufgd.edu.br; earmando24@gmail.com; JorgeCortez@ufgd.edu.br

${ }^{3}$ Universidade Federal do Vale do São Francisco, Departamento de Engenharia Agrícola e Ambiental, Juazeiro, Bahia, Brazil. Hideo.agro@gmail.com

*Corresponding author: salvionapoleao@gmail.com
} 
in sugarcane cultivations, there is still a low adoption of these systems, what could improve soil structure and yield, increasing the income. In studies of the agronomic performance of the sugarcane plant cultivar SP 81-3250, in Dystroferric Red clay Oxisol in region of Rio Brilhante, in State of Mato Grosso do Sul, under three conventional soil preparation systems, Silva Junior et al. (2013) observed that minimum tillage and harrowing soil preparation showed low yield values of the stalks and Pol, when compared to the other soil preparation systems. Contrarily, Tavares et al. (2010) observed that the treatment sugarcane removal, under conventional soil preparation system and minimal tillage, were statistically equal in yield, suggesting that to observe differences under both soil preparations systems need a large period to be significant.

Under the same farming environmental conditions, varieties may express differently their genetic potential, thus, an influence in production components, such as crop height and diameter of stalks and tillering (Oliveira et al., 2004; Costa et al., 2011; Morais et al., 2017), in the same farming cycle or in successive cycles. In addition, these components are more correlated to stalks yield and tillering (Silva et al., 2008; Morais et al., 2017), especially under adequate soil water availability conditions, enabling the varieties to express their highest genetic potential (Silva et al., 2014). Abreu et al. (2013) emphasized that the knowledge of the cultivar growth performance during the production cycle of the varieties is important to enable planning the production to match the periods of maximum growth to the ones of greater water availability, aiming at the increase of the production of the crop.

Thus, Silva et al. (2014) evaluating sugarcane cultivars observed differences for stalks yield and sugar yield content, due to genetic issues, highlighting that the cultivar RB855536 had low yield among the others. Moreover, when evaluating sugarcane plant cultivars of earl maturation, Veríssimo et al. (2012) observed that the RB966928 showed high Brix yield and huge adaptability, while the standard cultivar RB855156 showed a moderate stabilization and specific adaptation.

When planning the sugar-cane production, several factors must be considered to maximize the yield. Thus, sugar-cane varieties management is one of the main strategies that allows sorting the local varieties for different local edaphic-climatic local conditions. In this context to guarantee the sugarcane energetic sector sustainability, is necessary to understand the performance of cultivars under conservationist soil management systems (Arcoverde et al., 2019a). Thus, this study aimed to evaluate the growth and agricultural productivity of sugarcane plant cultivars and their correlation with the soil mechanical penetration resistance in a Red Oxisol Dystroferric submitted to reduced tillage and no-tillage systems.

\section{MATERIAL AND METHODS}

\section{Localization and characterization of the experimental area}

The trial was conducted from July 2016 (stalks planting) to August 2017 (harvest) at the Experimental Farm of Agricultural Sciences of the Federal University of Grande Dourados (UFGD), in Dourados, MS (22 $13^{\prime} 58^{\prime \prime} \mathrm{S}, 54^{\circ}$ 59' 57' W and 418 m altitude), in Red Latosol Dystroferric, with a clayey texture, composed with $603 \mathrm{~g} \mathrm{~kg}^{-1}$ of clay layer up to $0.30 \mathrm{~m}$ depth, $147 \mathrm{~g} \mathrm{~kg}^{-1}$ of silt and, $250 \mathrm{~g} \mathrm{~kg}^{-1}$ of sand (Arcoverde et al., 2019a).

The climate type of this area is classified as Am, monsoon, with dry winter, annual precipitation average of $1.500 \mathrm{~mm}$, and an annual temperature average of 22 ${ }^{\circ} \mathrm{C}$ (Alvares et al., 2013). During the cane-plant farming cycle, was recorded the data of the accumulated rainfall average of $1.400 \mathrm{~mm}_{\text {year }}{ }^{-1}$ and an average temperature of $23 \mathrm{C}$ (Figure 1).

\section{Installation of the experiment}

The triall area was being conducted with soybean and corn under for 14 years ago in the system of crop succession without soil mobility. Additionally, the area presented the uniformity in the environment conditions, with a slowlevelled topography, with no soil variation and soil management. The trial area was divided into two sub-areas, composed by no-tillage and, reduced tillage soil preparation systems, where sugarcane cultivars (RB965902, RB985476, RB966928, RB855156, RB975201, RB975242, RB036066 and RB855536) were manually planted on July 21, 2016, in density of 15 stalks per meter (Arcoverde et al., 2019a; Arcoverde et al., 2019b). For each soil preparation system, the sugarcane cultivars were planted in a completely randomized design, and eight treatments and four replications. Each experimental unit contained 5 sugarcane - plants lines of 5 meters length, spaced in 1.50 $\mathrm{m}\left(37.5 \mathrm{~m}^{2}\right)$, adding up 32 experimental units per soil preparation system. The fertilizer rate for planting was uniform for the whole experimental area, with application of $0.3 \mathrm{Mg} \mathrm{ha}^{-1}$ of NPK compost in a formulation 10-25-26 (Arcoverde et al., 2019a; Arcoverde et al., 2019b).

\section{Soil preparation and crop managements}

The reduced soil preparation consisted on the mobilization with heavy harrowing. Thus, this was an offset harrowing-plough, completed at one pin, composed of 16 discs of $0.76 \mathrm{~m}$ of diameter in each section, working at the depth of $0.15 \mathrm{~m}$. The direct planting system consisted on controlled mechanized (straw crashing) of the weeds, and then planting farrow opening. The straw crasher was equipped with curved blade rotor, working in high rotation and planting furrow opening. At the time of preparation, 
the water content in the soil was $0.24 \mathrm{~kg} \mathrm{~kg}^{-1}$ and the soil mechanical strength at the mean mechanical penetration resistance of 2.48 MPa in the 0.00-0.20 m layer (Arcoverde et al., 2019b).

For the soil tillage and furrow opening operations, the New Holland 4x2, 8030 a tractor, 89.79 kW (122 hp) engine, $2200 \mathrm{rpm}, 3 \mathrm{rd}$ gear reduced, 14.9-58 front tires and rear tires 23.1-30 and, mass of 4.51 Mg was used. For furrows covering and phytosanitary treatment, was used the Massey Fergusson 4x2 TDA tractor, model MF292 engine power $68.74 \mathrm{~kW}, 2200 \mathrm{rpm}$, 3rd gear, 7.50-18 front tires and rear $18.4-34$, and mass of $3.40 \mathrm{Mg}$; and a sprayer KO Crosss 2000, with 9.5-24 tires, $14 \mathrm{~m}$ spray boom and, weight of 1.4 Mg (Arcoverde et al., 2019a; Arcoverde et al., 2019b).

The chemical control of weeds was performed with preemergence and post-emergence application on September 16, 2016, and October 2, 2016, respectively. The tebuthiuron concentrated suspension $\left(500 \mathrm{~g}\right.$ a.i. $\left.\mathrm{L}^{-1}\right)$ was applied at a dose of $2.4 \mathrm{~L} \mathrm{ha}^{-1}$. The haloxyfop-methyl formulation was applied at a dose of $0.5 \mathrm{~L} \mathrm{ha}^{-1}$. Additionally, the manual weeding was also performed during the sugarcane crop cycle.

\section{Biometry and productivity}

At 100, 125, 150, 215 and 395 days after planting (DAP), we evaluated the crop height, stalks diameter of ten plants from the three central lines of each experimental unit, considering $1.0 \mathrm{~m}$ of the ends of each line as border (Arcoverde et al., 2019a; Arcoverde et al., 2019b). The crop height measurements were performed using a graduated tape measure, of $0.1 \mathrm{~mm}$ resolution, measuring the distance from the stalks base to the collar (dewlap) of leaf +1 , according Abreu et al. (2013). The stalks diameter was performed using a pachymeter, according Arcoverde et al. (2019a) and Arcoverde et al. (2019b), measuring the base of the stalks, $5 \mathrm{~cm}$ from the ground.
At 70, 98, 126, 215 and 395 DAP, the number of tillers per meter (NTM) was obtained by counting the tillers in 3 meters of furrow in the 5 lines of the experimental unit, considering $1 \mathrm{~m}$ at the ends of the 5 lines as border, according Arcoverde et al. (2019b).

At 395 DAP, were determined the yield of stalks (TCH) from the stalks weighs and the relation between the weight and the number of stalks, pointing out the results in $\mathrm{kg}$ stalks $^{-1}$ and, later, the data was extrapolated to mega-grams per hectare (Prellwitz \& Coelho, 2011). Then a bundle of industrialized stalks was submitted to the laboratory technological analysis to obtain sucrose concentration (polarization). The yield of sugar content (TPH) we obtained by means of the product between the TCH and the cane divided by 100 (Abreu et al., 2013).

\section{Mechanical soil penetration resistance and soil moisture}

At the total sugarcane growth stage, 180 DAP, were evaluated the soil mechanical penetration resistance (PR) and soil moisture in both soil preparation systems. In each experimental unit, were collected deformed soil samples at three points in the $0.00-0.10$ layers; $0.10-0.20 ; 0.20-0.30$ and $0.30-0.40 \mathrm{~m}$, at $0.10 \mathrm{~m}$ from the planting furrow. The gravimetric moisture of the samples was determined according to Donagema et al. (2011). The PR (soil resistance to penetration) performed with PenetroLOG PLG 1020 field penetrometer, by determining the mean PR and maximum PR stratified in the layers of 0.00-0.10; 0.100.20; 0.20-0.30; 0.30-0.40 m (Arcoverde et al., 2019a). Thus, five sampling points were considered in the positions: cane line and between tractor rolling tires.

\section{Statistical analyzes}

Was performed the regression analysis for stalks height, stalks diameter and NPM, and the curve that best fit each

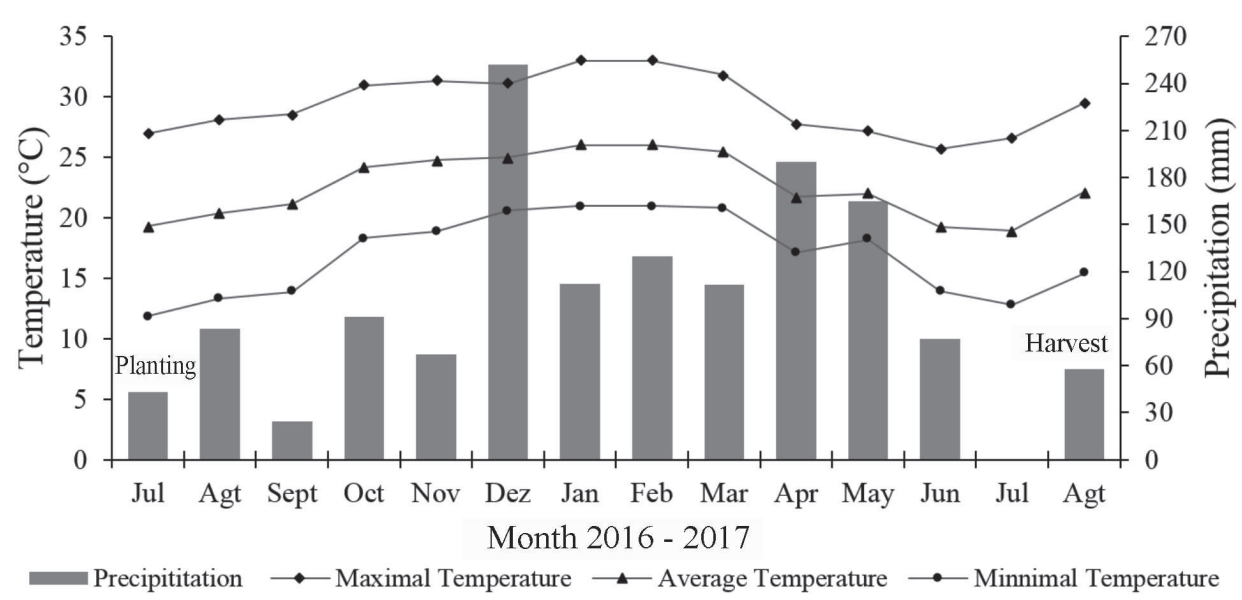

Figure 1: Monthly meteorological data on sugarcane cultivation (cane-plant) in the experimental area during the period, from July 2016 (planting) to August 2017 (harvest).

Rev. Ceres, Viçosa, v. 66, n.3, p. 168-177, mai/jun, 2019 
data display regarding to determination coefficient, significance of the regression coefficients at $1 \%$ of probability test. The data of TCH and TPH was submitted to variance analysis ( $\mathrm{F}$ - test), in a combined experiments (soil preparation). In this analysis, when observed the interaction between experiment and cultivars (factorials $8 \times 2$ ), was performed the individual analysis of the cultivars within the soil preparation systems. The mean values were compared to Student-Newman-Keuls, test $5 \%$ probability. The comparisons between soil tillage for soil moisture and soil mechanical penetration resistance was performed (mean PR and maximum PR) through t-test for independent samples $(\mathrm{p}<0.05)$. The statistical analysis was performed with AGROESTAT software package (Barbosa \& Maldonado Júnior, 2015).

\section{RESULTS AND DISCUSSION}

\section{Plant growth}

The biometric parameters of the cane-plant cycle showed that the stalks height adjusted to the quadratic linear regression model, for all cultivars, either for no-tillage or in reduced tillage (Figure 2). Moreover, the stem diameter in all cultivars, adjusted to square root linear regression model, except to cultivar RB975201, which presented a quadratic linear regression model under reduced tillage (Figure 3). For the number of tillers per meter (NTM), all cultivars adjusted to square root linear regression model, for both soil preparation systems (Figure 4).

The stalks height showed an increase growth from the first to the last evaluation for all cultivars. All cultivars showed a slow growth up to 150 DAP, what has been expected, regarding up to the tillering stage of the crop, what enabled elongation of stems with a high potential at this growth phase.

The highest growth rates of the stalks were observed up to 215 DAP in the both soil preparation systems, which coincided to the stalks elongation phase increasing the sucrose accumulation levels. Another factor that contributed to this condition was the increase of rainfall and temperature (Figure 1), which favored the vegetative development of the crop.

In the same period, the cultivar RB985476, showed its maximum rates of $2.20 \mathrm{~cm} \mathrm{day}^{-1}$ and $2.13 \mathrm{~cm}_{\text {day }}{ }^{-1}$ under no-tillage and reduced tillage, respectively; while the minimum rates of $1.25 \mathrm{~cm} \mathrm{day}^{-1}$, in the cultivar RB855156 were observed under reduced tillage, and $1.44 \mathrm{~cm} \mathrm{day}^{-1}$ in the cultivar RB975201 under no-tillage.

From the maximum rates, was observed a reduction of stalks growth due to the beginning of the maturation phase of the crop and also to the reduction of the precipitation, corroborating to Tavares et al. (2010) and Abreu et al. (2013) when evaluating the growth of cane-plant and cane- shoots. Additionally, was verified that, either in reduced tillage or in no-tillage, RB966928 had higher stalks growth at the end of the crop cycle while the RB855536, showed the lowest one. It is noteworthy that the reduction of shoots growth at the maturation stage is extremely favorable for the industry, since the plant directs its photo-assimilates to the accumulation of sucrose, instead of directing them to shoots elongation.

The results showed that the growth rate of the stalks had similar behavior to those observed by Santos et al. (2009) and Abreu et al. (2013), which characterized three stages of the crop development: the first of slow growth; the second with accelerated growth and the third with decreasing growth and maturation rates.

Abreu et al. (2013) emphasized that the knowledge of the growth patterns during the production cycle of the varieties is important when planning the production to adjust the periods of maximum growth to the ones of greater water availability, aiming at the increase of the production of the crop.

In general, all the evaluated cultivars presented higher daily stalks growth rate when cultivated under no-tillage than when cultivated in reduced tillage. These results are related to the lower values of the mechanical penetration resistance, in the layer $0.20-0.40 \mathrm{~m}$, under no-tillage when compared to the reduced tillage, with maximum PR values, due to the lower values of soil moisture observed (Table 1).

Arcoverde et al. (2019a) observed that more than $90 \%$ of sugar-plant roots develop in the layers 0.00-0.20 and $0.20-0.40 \mathrm{~m}$ (Cury et al., 2014), and $75 \%$ of the roots are in the first $0.45 \mathrm{~m}$ of depth in dry or irrigated condition (Farias et al., 2008). Moreover, Sá et al. (2016) observed that values of PR above $3.8 \mathrm{MPa}$ for the cultivation of sugarcane cultivated in clay soil $\left(600 \mathrm{~g} \mathrm{~kg}^{-1}\right)$ may interfere on root mass reduction.

The diameter of stalks showed a highest growth in the period between 150 and 215 DAP, for all cultivars under both soil preparation systems (Figure 3 ). This issue is related to the end of the tillering phase and the beginning of the stalk growth stage with greater internodes elongation in order to increase sucrose accumulation points.

In addition, there was observed a maximum stalk diameter at approximately 300 DAP, with a slight decrease until harvest (395 DAP), for all cultivars, in both soil preparation systems, what might probably be related to the shade presence, reducing the luminosity, interfering in the increase of stalk diameter as observed by Tavares et al. (2010).

Analyzing the linear regression models for NPM (Figure 4), was observed higher growth between 70 and 98 DAP, 126 and 215 DAP for all cultivars in both soil preparation systems, in comparison to the other evaluated periods. This situation dues to the interference of favorable 
environmental conditions from the 70 DAPs, else what, with the beginning of the rainy season in October, raised the water availability, as well as to the high average temperatures (Figure 1).

In general, in reduced soil preparation system was observed, maximum tillering between 200 and 250 DAP for all cultivars, from which was observed a reduction up to 395 DAP. However, in reduced soil preparation system, the cultivars RB855156 (early) and RB975201 (late) showed an increase in NTM at the end of the cane plant farming cycle. The mean value of NTM reduced (32 and 23\%) in cultivar RB855536, submitted no-tillage and under reduced tillage, respectively, and was also observed reduction of
$17 \%$ in RB036066, in both soil preparation systems. Costa et al. (2011), highlights that the reduction in tillering has been attributed to the intraspecific competition increased of the growth factors such as water, light, nutrient and shelter, leading to death of new weak tillers and misspositioned.

Moreover, all cultivars showed a greater initial tillering index under a reduced tillage system when compared to no-tillage, except to RB985476 and RB975242, which presented higher tillering under reduced tillage during the whole cane-plant farming cycle. These results are in concordance to the ones observed by Tavares et al. (2010) when evaluating
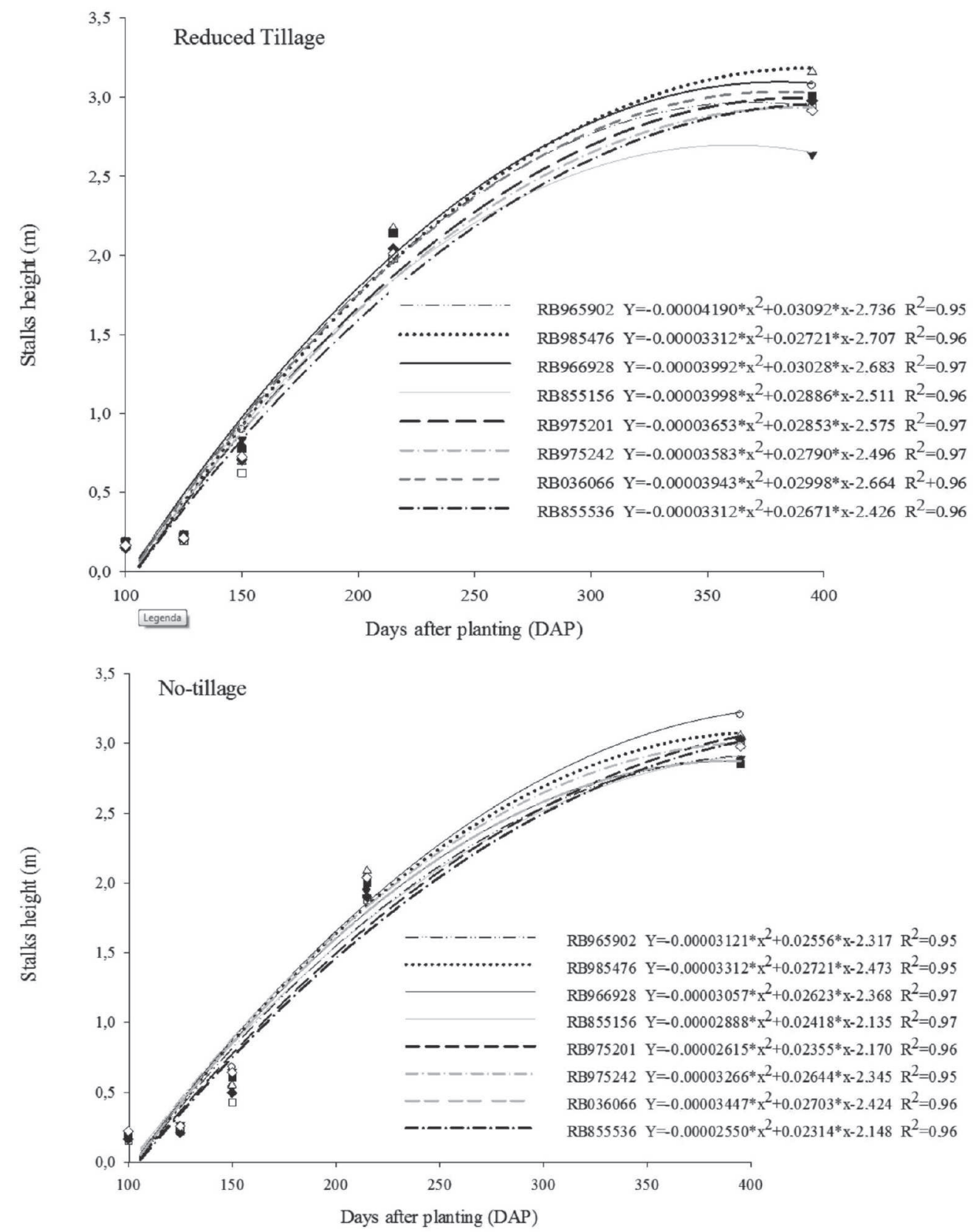

Figure 2: Estimators of the plant height $(\mathrm{m})$ of eight sugarcane cultivars during the cane-plant farming cycle, under reduced tillage and no-tillage. $* *$ : significant $(\mathrm{p}<0.01)$. 
tillering in cane-plant and shoots under mobilized soil and no-tillage; hence, these authors observed that the mobilization favored the increase of macroporosity on the surface layer and reduced the soil bulk density, enabling lower PR and high crop stand.

When analyzing the cultivars under maturation cycle was observed a similar behavior for the early to medium maturation cultivars in relation to the growth in NPM under no-tillage and reduced tillage. These showed a maximum tillering during the vegetative growth phase, followed by a decrease at the end of this phase and the beginning of maturation. This result was expected for the early cultivars and also the high tillering characteristic of cultivars RBRB965902, RB985476, RB966928 and RB036066.

The cultivar RB855156 showed an exception in the group of earl cultivar, with a different growth due to soil preparation system, showing a decrease in tillering under reduced tillage and tillering increase until harvest in notillage. A similar behavior was observed for the late maturing
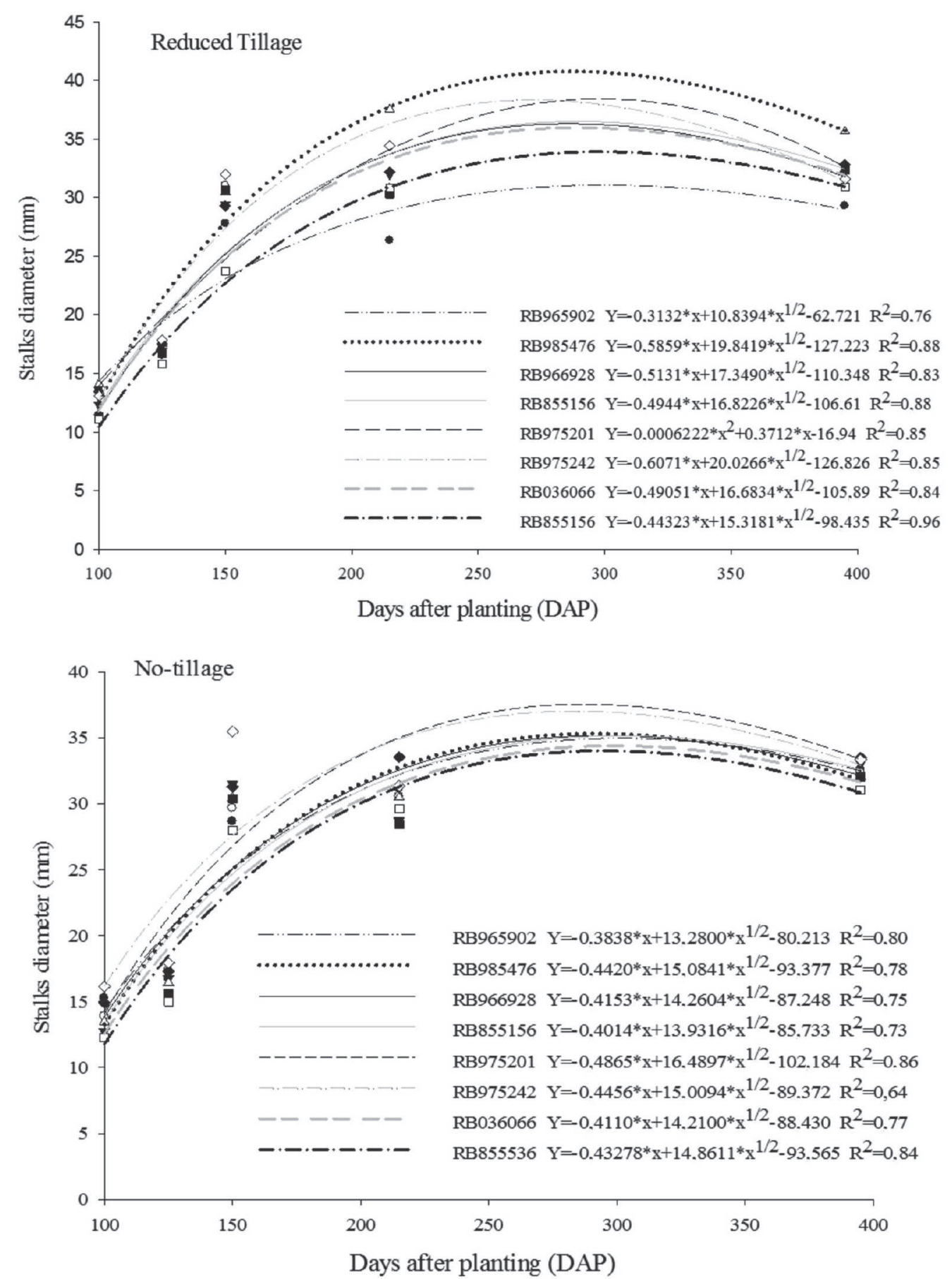

Figure 3: Estimators of stalks diameter $(\mathrm{mm})$ of eight sugarcane cultivars during the cane-plant farming cycle, under reduced tillage and no-tillage. ${ }^{* *}$ : significant $(\mathrm{p}<0.01)$. 
cultivars RB975201 and RB975242. These results support the hypothesis that the best physical-water conditions in the soil under no-tillage (Table 1) favor the continuity of the late cultivar cycle, which did not occur under the reduced tillage, showing the effect of the environment in tillering restriction.

Possibly, the higher values of soil moisture in the deep layers $(0.20-0.40 \mathrm{~m})$ under no-tillage (Table 1$)$ favored the higher tillering of the cultivars in this system from the initial growth phase, when compared to the reduced tillage.

Hence, according to Tavares et al. (2010), although the better soil structure under no-tillage due to the ploughing only in planting, conduced to low evaporation enabled by the maintenance of vegetal remains, this, also resulted in differences in soil penetration resistance. Moreover, was observed low values of PR under no-tillage, on regard to
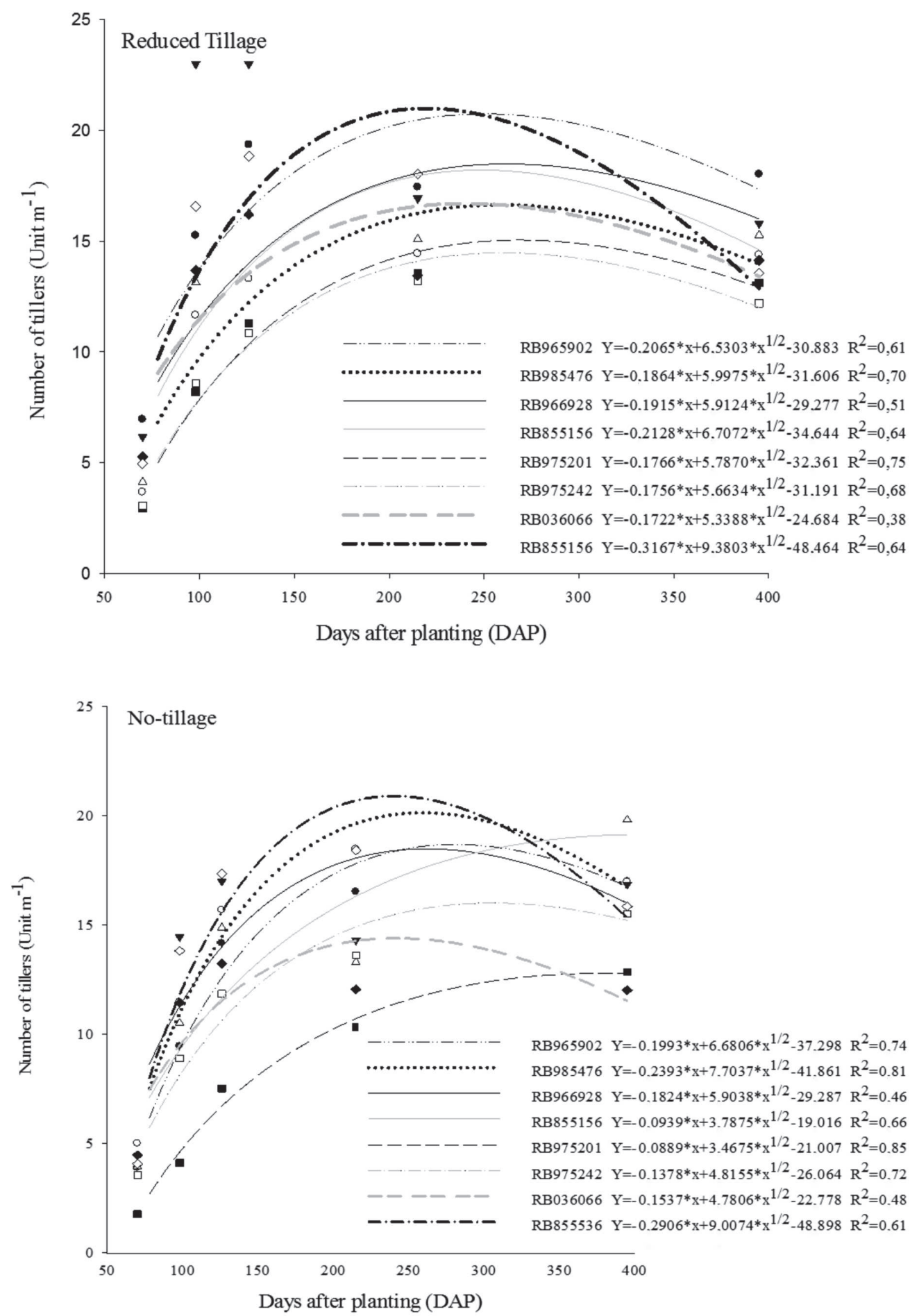

Figure 4: Estimates of the number of tillers per meter (NPM) of the eight sugarcane cultivars during the cane-plant farming cycle submitted to reduced tillage and no-tillage. $* *$ : significant $(\mathrm{p}<0.01)$.

Rev. Ceres, Viçosa, v. 66, n.3, p. 168-177, mai/jun, 2019 
reduced tillage (Table 1), showing the effects of soil tillage in the appearance of more compacted layers in deeper soil areas. Oliveira et al. (2015) point out that such differences for PR are indicative of variation in soil structure and/or moisture at the time of sampling between soil preparation systems.

According to Morais et al. (2017), the height and diameter variables of the stalks are the main components that most correlate with the yield of stalks associated with the tillering, what was affirmed by Silva et al. (2014), especially under adequate soil water availability, enabling the varieties to express their better genetic, highly correlated to soil moisture levels, hence, the greater the soil water availability, the greater the crop growth. On the other hand, the longer the drought period, the greater the formation of nodes and very short are the internodes and close to each other, thus, significantly reducing the parenchyma volume for sucrose storage (Câmara, 1993).

\section{Agricultural productivity}

The ANOVA was not significant in the interaction of the factors experiment and cultivars for the variables yield of stalks (TCH) and sugar yield (TPH), what was observed only for the singular effect of the factors. During the caneplant farming cycle, there was observed a significant difference for the TCH and TPH among cultivars, with a higher value for RB965902, RB985476, RB966928, RB855156, and lower for RB855536 cultivars respectively (Table 2). Moreover, no difference was observed from RB975201, RB975242, RB036066, which in general, the medium to late maturation, contributed to lower stalks growth rate, leading to a lower final stalks number.
The TCH and TPH showed higher values under notillage when compared to reduced tillage, what can be related to the better physical-water conditions of the soil in the zone of high concentration of the crop root system. There was also pointed out that these variables are highly influenced by the variety, the farming environment conditions and, above all, the availability of water since sugar content is adversely affected by excess moisture at the maturation stage (Silva et al., 2014).

Machado et al. (2009) when studying phenological stages of the crop under soil water deficit, verified reduction of the dry matter of the stalks and soluble solids content caused by the reduction of photosynthesis, reducing photo assimilates production required for stem growth and sucrose production. Inman-Bamber \& Smith (2005),

Table 2: Mean of the stalks yield (TCH) and sugar yield content (TPH) evaluated submitted to no-tillage and reduced tillage

\begin{tabular}{lll}
\hline \multirow{2}{*}{ Treatment } & \multicolumn{1}{c}{ TCH } & TPH \\
\cline { 2 - 3 } & \multicolumn{2}{c}{ Mg ha $^{-1}$} \\
\hline RB965902 & $171.57 \mathrm{ab}$ & $25.64 \mathrm{ab}$ \\
RB985476 & $174.74 \mathrm{a}$ & $26.38 \mathrm{ab}$ \\
RB966928 & $166.75 \mathrm{ab}$ & $25.72 \mathrm{ab}$ \\
RB855156 & $172.89 \mathrm{ab}$ & $27.10 \mathrm{a}$ \\
RB975201 & $140.10 \mathrm{abc}$ & $19.56 \mathrm{c}$ \\
RB975242 & $150.00 \mathrm{abc}$ & $21.66 \mathrm{bc}$ \\
RB036066 & $138.61 \mathrm{bc}$ & $16.83 \mathrm{c}$ \\
RB855536 & $131.58 \mathrm{c}$ & $18.28 \mathrm{c}$ \\
No-tillage & $164.80 \mathrm{a}$ & $24.00 \mathrm{a}$ \\
Reduced tillage & $146.76 \mathrm{~b}$ & $21.25 \mathrm{~b}$ \\
\hline
\end{tabular}

The similar letters do not differ by Student-Newman-Keuls, test $5 \%$ probability. TCH: stalks yield; TPH: sugar yield content.

Table 1: Mean values of soil moisture, soil mechanical strength at average penetration (mean PR) and maximum (maximum PR) determined on the field (PR) per soil layer under soil tillage and sampling position

\begin{tabular}{|c|c|c|c|c|c|}
\hline \multirow{4}{*}{ Preparation } & \multirow{4}{*}{$\begin{array}{l}\text { Soil moisture } \\
\quad \mathrm{kg} \mathrm{kg}^{-1}\end{array}$} & \multicolumn{4}{|c|}{ Mechanical penetration resistance (PR) } \\
\hline & & \multicolumn{2}{|c|}{ Mean } & \multicolumn{2}{|c|}{ Maximum } \\
\hline & & Inter tires & Row & Inter tires & Rows \\
\hline & & \multicolumn{4}{|c|}{ MPa } \\
\hline & \multicolumn{5}{|c|}{$0.00-0.10 \mathrm{~m}$} \\
\hline Reduced & $0.22 \mathrm{a}$ & $1.18 \mathrm{a}$ & $0.81 \mathrm{a}$ & $2.54 \mathrm{a}$ & $1.87 \mathrm{a}$ \\
\hline \multirow[t]{2}{*}{ No-tillage } & $0.22 \mathrm{a}$ & $1.29 \mathrm{a}$ & $0.67 \mathrm{a}$ & $2.66 \mathrm{a}$ & $1.69 \mathrm{a}$ \\
\hline & \multicolumn{5}{|c|}{$0.10-0.20 \mathrm{~m}$} \\
\hline Reduced & $0.21 \mathrm{~b}$ & $2.14 \mathrm{a}$ & $1.57 \mathrm{a}$ & $3.31 \mathrm{a}$ & $2.74 \mathrm{a}$ \\
\hline \multirow[t]{2}{*}{ No-tillage } & $0.22 \mathrm{a}$ & $2.10 \mathrm{a}$ & $1.29 \mathrm{a}$ & $3.27 \mathrm{a}$ & $2.45 \mathrm{a}$ \\
\hline & \multicolumn{5}{|c|}{$0.20-0.30 \mathrm{~m}$} \\
\hline Reduced & $0.20 \mathrm{~b}$ & $2.40 \mathrm{a}$ & $2.16 \mathrm{a}$ & $3.48 \mathrm{a}$ & $3.15 \mathrm{a}$ \\
\hline \multirow[t]{2}{*}{ No-tillage } & $0.24 \mathrm{a}$ & $2.07 \mathrm{~b}$ & $1.75 \mathrm{~b}$ & $2.90 \mathrm{~b}$ & $2.73 \mathrm{~b}$ \\
\hline & \multicolumn{5}{|c|}{$0.30-0.40 \mathrm{~m}$} \\
\hline Reduced & $0.20 \mathrm{~b}$ & $2.66 \mathrm{a}$ & $2.42 \mathrm{a}$ & $3.59 \mathrm{a}$ & $3.23 \mathrm{a}$ \\
\hline No-tillage & $0.24 \mathrm{a}$ & $1.99 \mathrm{~b}$ & $2.06 \mathrm{~b}$ & $2.68 \mathrm{~b}$ & $2.78 \mathrm{~b}$ \\
\hline
\end{tabular}

Mean values followed by letters compare sampling site with soil preparation, the similar letters do not differ by Student t test, $5 \%$ probability. 
observed greater susceptibility of sugarcane to water deficiency when the plants are in the growth phase of stems, which causes serious losses in phytomass production and sucrose yield. Thus, was observed the highest extension of the rate of daily elongation stalks, yield of stalks and sugar content for varieties cultivated under no-tillage.

\section{CONCLUSIONS}

We observed the highest rates of daily elongation stalks, stalks yield and sugar under no-tillage, due to the lower soil penetration resistance and higher soil moisture.

The cultivar RB966928 presented higher growth and yield of stalks and sugar content, while RB855536 and the medium to late maturity cultivars RB975201, RB975242, RB036066, which had either a lower stalk growth rate or presented lower number at the end of the crop cycle for both soil preparation systems.

\section{ACKNOWLEDGMENTS, FINANCIAL SUPPORT AND FULL DISCLOSURE}

Acknowledgments due to the Fundação par Apoio ao Desenvolvimento e Educação, Ciência e Tecnologia (Foundation for the Support to Development of Education, Science and Technology) of the State of Mato Grosso do Sul (FUNDECT). This study was financed in part by the Coordenação de Aperfeiçoamento de Pessoal de Nível Superior-Brasil (CAPES) - Finance Code 001. The authors also thank CNPq and CAPES for the research and $\mathrm{PhD}$ grants awarded, respectively.

\section{REFERENCES}

Abreu ML, Silva MA, Teodoro I, Holanda LA \& Sampaio Neto GD (2013) Crescimento e produtividade de cana-de-açúcar em função da disponibilidade hídrica dos Tabuleiros Costeiros de Alagoas. Bragantia, 72:262-270.

Alvares CA, Stape JL, Sentelhas PC, Gonçalves JLM \& Spavorek G (2013) Köppen's climate classification map for Brazil. Meteorologische Zeitschrift, 22:711-728.

Arcoverde SNS, Souza CMA, Cortez JW, Maciak PAG \& Suárez AHT (2019a) Soil physical attributes and production components of sugarcane cultivars in conservationist tillage systems. Revista Engenharia Agrícola, 39:216-224.

Arcoverde SNS, Souza CMA, Orlando RC, Silva MM \& Nascimento J (2019b) Crescimento inicial de cultivares de cana-de-açúcar em plantio de inverno sob preparos conservacionistas do solo. Revista Engenharia na Agricultura, 27:142-156.

Barbosa JC \& Maldonado Junior W (2015) AgroEstat - sistema para análises estatísticas de ensaios agronômicos. Jaboticabal, FCAV/UNESP. 396p.

Câmara GMS (1993) Ecofisiologia da cultura da cana-de-açúcar. In: Câmara, GMS Produção de cana de açúcar. Anais, ESALQ. p.31-64.
Carvalho LA, Silva Junior CA, Nunes AGA, Meurer I \& Souza Junior WS (2011) Produtividade e viabilidade econômica da cana-de-açúcar em diferentes sistemas de preparo do solo no Centro-oeste do Brasil. Revista de Ciências Agrárias, 34:200211.

Costa CTS, Ferreira VM, Endres L, Ferreira DTRG \& Gonçalves ER (2011) Crescimento e produtividade de quatro variedades de cana-de-açúcar no quarto ciclo de cultivo. Revista Caatinga, 24:56-63.

Cury TN, De Maria IC \& Bolonhezi D (2014) Biomassa radicular da cultura de cana-de-açúcar em sistema convencional e plantio direto com e sem calcário. Revista Brasileira de Ciência do Solo, 38:1929-1938.

Donagema GK, Campos DVB, Calderano SB, Teixeira WG \& Viana JHM (2011) Manual de métodos de análise de solos. $2^{\mathrm{a}}$ ed. Rio de Janeiro, Embrapa Solos. 230p. (Embrapa Solos. Documentos, 132).

Farias CHA, Fernandes PD, Azevedo HM \& Dantas Neto J (2008) Índices de crescimento da cana-de-açúcar irrigada e de sequeiro no Estado da Paraíba. Revista Brasileira de Engenharia Agrícola e Ambiental, 12:356-362.

Inman-Bamber NG, Bonnett GD, Smith DM \& Thorburn PJ (2005) Sugarcane physiology: integrating from cell to crop to advance sugarcane production. Field Crops Research, 92:115-117.

Machado RS, Ribeiro RV, Marchiori PER, Machado DFSP, Machado EC \& Landell MGA (2009) Respostas biométricas e fisiológicas ao déficit hídrico em cana de açúcar em diferentes fases fenológicas. Pesquisa Agropecuária Brasileira, 44:1575 1582.

Morais KP, Medeiros SLP, Anjos e Silva SD, Biondo LC, Boelter JH \& Dias FS (2017) Produtividade de colmos em clones de cana-de-açúcar. Revista Ceres, 64:291-297.

Oliveira DMS, Lima RP \& Verburg EEJ (2015) Qualidade física do solo sob diferentes sistemas de manejo e aplicação de dejeto líquido suíno. Revista Brasileira de Engenharia Agrícola e Ambiental, 19:280-285.

Oliveira RA, Daros E, Zambon JL, Weber H, Ido OT, ZuffellatoRibas KC, Koehler HS \& Solva DKT (2004) Crescimento e desenvolvimento de três cultivares de cana-de-açúcar, em canaplanta, no estado do Paraná. Scientia Agraria, 05:87-94.

Prellwitz WPV \& Coelho FC (2011) Produtividade de colmos, índice de área foliar e acúmulo de $\mathrm{N}$ na soca de cana-de-açúcar em cultivo intercalar com Crotalaria juncea L. Revista Ceres, 58:773-780.

Sá MAC, Santos Junior JDG, Franz CAB \& Rein TA (2016) Qualidade física do solo e produtividade da cana-de-açúcar com uso da escarificação entre linhas de plantio. Pesquisa Agropecuária Brasileira, 51:1610-1622.

Santos VR, Moura Filho G, Albuquerque AW, Costa JPV, Santos CG \& Santos ACI (2009) Crescimento e produtividade agrícola de cana-de-açúcar em diferentes fontes de fósforo. Revista Brasileira de Engenharia Agrícola e Ambiental, 13:389-396.

Silva AA \& Castro SS (2015) Indicadores macro e micromorfológicos da qualidade física de um Latossolo Vermelho cultivado com cana-de-açúcar. Mercator, 04:169-185.

Silva Junior CA, Carvalho LA, Centurion JF \& Oliveira ECA (2013) Comportamento da cana-de-açúcar em duas safras e atributos físicos do solo, sob diferentes tipos de preparo. Bioscience Journal, 29:1489-1500.

Silva MA, Arantes MT, Rhein AFL, Gava GJC \& Kolln OT (2014) Potencial produtivo da cana-de-açúcar sob irrigação por gotejamento em função de variedades e ciclos. Revista Brasileira de Engenharia Agrícola e Ambiental, 18:241-249. 
Silva MA, Jerônimo EM \& Lúcio AD (2008) Perfilhamento e produtividade de canade-açúcar com diferentes alturas de corte e épocas de colheita. Pesquisa Agropecuária Brasileira, 43:979986

Tavares OCH, Lima E \& Zonta E (2010) Crescimento e produtividade da cana planta cultivada em diferentes sistemas de preparo do solo e de colheita. Acta Scientiarum Agronomy, 32:6168.
Veríssimo MAA, Silva DAS, Aires RF, Daros E \& Panziera W (2012) Adaptabilidade e estabilidade de genótipos precoces de cana-de-açúcar no Rio Grande do Sul. Pesquisa Agropecuária Brasileira 47:561-568. 